WINDSCALE

\title{
Down to business
}

The Windscale inquiry opened in Whitehaven, Cumbria, last week. Chris Sherwell reports

No ONE thinks a decision on Windscale is going to be easy; the case is too finely balanced. But practically everyone involved in the inquiry, on the application from British Nuclear Fuels Ltd (BNFL) to develop land there for an oxide fuel reprocessing plant, hopes that the decision will go their way. Once Mr Justice Parker has made his recommendations, probably by the autumn, the responsibility will lie with the Secretary of State for the Environment. Assuming the Labour government survives until then, that will be Mr Peter Shore.

Opening statements from BNFL and from the various opponents of the project were heard last week. Crossexamination of some 18 witnesses to be brought by BNFL also began. The first was $\mathrm{Mr}$ Con Allday, the managing director, and he was still on the stand on Friday. Before he appeared the inquiry already looked like broadening the spread of issues it will cover when Mr Justice Parker produced over a dozen points on which he said he and his two assessors wanted early clarification from BNFL.

The points drew attention to figures showing that plutonium recovered through reprocessing would be enough to charge more fast breeder reactors than the country could possibly need. Mr Justice Parker said they wanted to know if one objective was to keep the breeder option open. They also wanted to know how much plutonium was required to fuel a breeder and how much had been recovered and would be recovered from spent Magnox fuel.

The implication was that existing facilities at Windscale for reprocessing oxide fuel--using the 'head-end' plant which is presently inoperative-might cope with domestic reprocessing demands and take some overseas business, and with other work also satisfy Britain's plutonium requirements. In short, was a new plant necessary?

This all fitted with what $\mathrm{Mr}$ Justice Parker had said at the start of the whole proceedings about three basic questions needing answers. These were: should spent oxide fuel be reprocessed in Britain at all? If yes, should it be reprocessed at Windscale? If yes, should the plant be larger than that required for domestic purposes in order to reprocess fuel from abroad?

In the context of these questions it was hardly surprising that the precise terms of the Japanese contract that BNFL has been trying over many months to negotiate also became important soon after $\mathrm{Mr}$ Allday took the stand. He was reluctant to furnish the document, yet plainly, without the terms of the proposed contract, no detailed assessment could be made of the financial and economic factors which, for the third question at least, BNFL themselves must regard as relevant. Sight of the terms was subsequently allowed.

Under cross-examination $\mathrm{Mr}$ Allday admitted it would be cheaper to use refurbished or rebuilt facilities that existed, but said this would not be enough. $\mathrm{He}$ also endeavoured to explain why existing facilities to reprocess spent Magnox fuel from Britain's first generation reactors had failed to operate at full design capacity. He attributed this at least partly to the difficulty of handling spent fuel elements that were in a poor condition because they had stayed in reactors too long. Also broached was the question of what work was being done on dealing with fuel if it should not be reprocessed.

Earlier in the week the inquiry had opened amid a burst of publicity generated by the presence in Whitehaven of nuclear experts, company men, government officials, lawyers, environmentalists, demonstrators and journalists. Many detected a note of resentment among the local people who have to live with Windscale. But the resentment was less at the plant, expansion of which means more jobs, than at the foreign invasion. Non-BNFL voices supporting the project because of the benefits it would bring to the area came from Cumbria County Council and Copeland Borough Council. But another authority, the Isle of Man, is among the objectors, not all of whom agree on the basis from which their arguments can best be launched.

Before the inquiry opened BNFL confirmed that a laboratory at Windscale had been closed following an accident six weeks earlier in which a pressurised glove-box had blown back and released plutonium. During the week, as part of a new policy of directly releasing details of all accidents no matter how trivial, BNFL published a list of incidents that had occurred over the previous two months. These details are usually passed on to the Nuclear Installations Inspectorate and to the Secretary of State for Energy.

The inquiry continued this week with more evidence from $\mathrm{Mr}$ Allday. Other BNFL witnesses were also to appear. $\square$
URANIUM

\section{Hot topic}

A TEAM of experts from Australia is thought to be in Europe to discuss possible sales of uranium for EEC nuclear power stations. They were expected to visit Brussels to discuss marketing arrangements and review Euratom security controls. The Australian Prime Minister, Mr Malcolm Fraser, visited Brussels last week for talks with the European Commission. He told reporters afterwards that his government had not yet decided on its export policy for uranium. An announcement is expected within weeks now that the second report of the Fox Commission has been published.

In spite of speculation to the contrary, Mr Fraser said that there was no question of a trade-off between possible exports of Australian uranium and greater access to EEC markets for Australian agricultural produce. Overall commercial relations between Australia and the EEC can, however, be expected to influence the matter, and Mr Fraser has attacked the EEC's Common Agricultural Policy.

Mr Fraser would not answer questions about Australia's alleged membership of a world-wide uranium cartel, into which further probings were made in the United States last week when a bundle of internal memoranda of the Gulf Oil Corporation was released by a Congressional subcommittee. They seriously undermine Gulf's contention that it was an unwilling partner in the cartel, and contradict its assertion that the operation of the cartel had no effect on domestic uranium prices in the United States. The memoranda, which were supplemented by a threeand-a-half hour grilling of Gulf's chairman, Jerry McAfee, could pose serious problems for Gulf's defence against possible anti-trust suits.

McAfee persistently claimed at the hearing that Gulf's Canadian mining subsidiary was pushed into the cartel by the Canadian government. He did not give details, however, and some of the internal memoranda depict the company as a willing partner. One memorandum even discussed how the cartel could eliminate competition from other uranium companies. The cartel vas formed in 1972, and operated until 1974 , a period when uranium prices increased sharply. McAfee and other Gulf officials admitted in their testimony that the increasing world price of uranium had, to a limited extent, also driven up domestic prices in the United States.

The second annual meeting of the Uranium Institute was meanwhile due to take place in London this week. The institute, established in June 1975, exists "to promote discussion between uranium producers and consumers", particularly on uranium supply and demand. It has 36 members, including 21 producers and 9 consumers. There are no US members. The institute's secretary gneral, Mr Terry Price, was among those called to give evidence before a US judge at the US embassy in London last week in connection with a case brought by Westinghouse Electric Corporation concerning the cartel. 